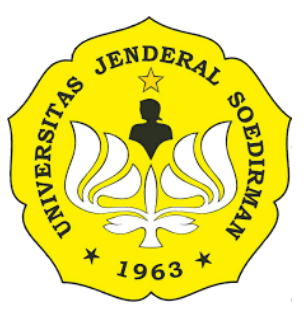

SOEDIRMAN ECONOMICS EDUCATION JOURNAL http://jos.unsoed.ac.id/index.php/seej/

\title{
PENGARUH MOTIVASI, GAYA BELAJAR DAN LINGKUNGAN SEKOLAH TERHADAP HASIL BELAJAR DI SMKN 1 GEGER
}

\author{
Sanita Oktari Andriyani ${ }^{1}$, Supri Wahyudi Utomo ${ }^{1}$, dan Liana Vivin Wihartanti ${ }^{1}$ \\ 1Jurusan Pendidikan Akuntansi, Universitas PGRI Madiun, Indonesia \\ sanita1210@gmail.com, supriutomo@unipma.ac.id, lianavivin@unipma.ac.id
}

\begin{abstract}
ABSTRAK
Penelitian ini dilakukan untuk mengetahui pengaruh motivasi, gaya belajar serta lingkungan sekolah sebagai variabel terhadap hasil belajar siswa. Penelitian ini menggunakan metode kuantitatif. Peneliti mengumpulkan data dari penyebaran kuesioner (Primer) kepada sampel sebanyak 76 siswa, serta data daftar nilai siswa (Sekunder). Kuesioner ini di uji dengan uji validitas dan uji reabilitas. Hasil penelitian ini menunjukkan bahwa motivasi, gaya belajar serta lingkungan sekolah terdapat pengaruh yang signifikan dan positif terhadap hasil belajar. Uji f menunjukkan bahwa motivasi, gaya belajar dan lingkungan sekolah terdapat pengaruh yang signifikan dan simultan terhadap hasil belajar.
\end{abstract}

Kata Kunci: Motivasi, Gaya Belajar, Lingkungan Sekolah, Hasil Belajar.

\section{ABSTRACT}

This research was conducted to determine the effect of motivation, learning style and school environment as variables on student learning outcomes. This research uses quantitative methods. Researchers collected data from distributing questionnaires (Primary) to a sample of 76 students, as well as student grade list data (Secondary). This questionnaire was tested with validity and reliability tests. The results of this study indicate that motivation, learning styles and the school environment have a significant and positive influence on learning outcomes. $f$ test shows that motivation, learning style and school environment have a significant and simultaneous influence on learning outcomes.

Keyword: Motivation, Learning Style, School Environment, Learning Outcomes. 


\section{PENDAHULUAN}

Pendidikan adalah suatu kegiatan pembelajaran yang sangat berpengaruh terhadap dunia ilmu pengetahuan dan teknologi. Pendidikan sangat berperan penting untuk seseorang agar bisa menghadapi masa depan yang terus mengikuti perkembangan zaman. Pendidikan dapat membentuk kualitas yang baik terhadap kemajuan suatu bangsa. Pendidikan formal terdiri dari beberapa tahapan yaitu tahap pra-sekolah, tahap dasar, tahap menengah pertama, tahap menengah atas, dan tahap perguruan tinggi/Universitas. Sekolah adalah lembaga pendidikan formal yang menjadi peranan penting untuk menggali dan melatih potensi peserta didik.

Sekolah Menengah Kejuruan (SMK) adalah lembaga pendidikan formal yang membentuk pendidikan kejuruan di tingkat menengah atas. Pendidikan menengah kejuruan ini memiliki program-program pendidikan yang disiapkan untuk mengorientasikan peserta didik siap memasuki lapangan kerja dengan sikap profesional. SMK memberikan orientasi untuk mempersiapkan siswa bekerja di bidang khusus. Seperti yang ditetapkan pada Peraturan Pemerintah Nomor 19 Tahun 2005 Pasal 26 Ayat 3 yaitu satuan pendidikan kejuruan bertujuan untuk meningkatkan kecerdasan, pengetahuan, kepribadian, akhlak mulia, serta keterampilan untuk hidup mandiri dan mengikuti pendidikan lanjut sesuai dengan kejuruan yang digelutinya.

Untuk melaksanakan tujuan pendidikan, terdapat proses pembelajaran yang bisa berdampak pada hasil belajar seorang siswa. Menurut Purwanto (2011) hasil belajar yaitu perubahan personalitas siswa setelah melakukan proses pembelajaran sesuai dengan tujuan. proses belajar dapat dinyatakan berhasil apabila sekolah menciptakan lulusan-lulusan yang berkualitas. Keberhasilan ini dilihat dari proses pembelajaran dan hasil belajar seorang siswa. Abzani \& Leonard (2017) mengatakan bahwa terdapat dua faktor yang dapat mempengaruhi hasil belajar, yaitu faktor internal dan faktor eksternal. Faktor internal berasal dari dalam individu. sedangkan faktor eksternal berasal dari luar individu. Dalam hal ini, pendidikan tidak terlepas dari dilema yang dihasilkan dari hasil pembelajaran siswa.

Motivasi merupakan salah satu faktor yang dapat mempengaruhi hasil belajar seorang siswa. Motivasi belajar memiliki dampak besar pada hasil belajar siswa, karena motivasi berasal dari dalam diri individu dalam penelitiannya, meningkatnya motivasi siswa dalam belajar maka akan memberikan hasil yang baik dalam hasil belajar siswa. Sekolah memberikan peran penting dalam meningkatkan motivasi belajar siswa sehingga siswa dapat mencapai tujuan belajarnya dan mendapatkan hasil belajar yang maksimal. Slameto (2010) menyampaikan bahwa belajar merupakan suatu upaya yang dilakukan individu untuk mendapatkan hasil dari pengalamannya sendiri. Siswa diharapkan memotivasi dirinya agar dapat mencapai tujuan pembelajaran. Tanpa adanya motivasi belajar, maka dorongan siswa dalam mencapai tujuan pembelajaran akan berkurang dan berpengaruh terhadap hasil belajar. 
Hasil belajar siswa tidak ditentukan dari motivasi belajar saja, hasil belajar siswa juga dapat ditentukan dari gaya belajar. Gaya belajar merupakan salah satu faktor yang dapat mempengaruhi hasil belajar siswa dalam menyerap suatu materi pembelajaran untuk mencapai tujuan pembelajaran. Gaya belajar siswa dilakukan dengan cara yang berbeda-beda, melalui gaya belajar visual, auditorial, dan juga kinestatik. Gaya belajar yang sesuai dengan diri siswa akan memberikan dorongan kepada siswa dalam memahami materi dan menyerap ilmu pengetahuan. Menurut Khoeron dkk (2014) semakin sesuai gaya belajar dengan keperibadian siswa, maka akan memudahkan siswa dalam mencapai hasil belajar. Kesalahan pemilihan gaya belajar yang dilakukan oleh siswa dapat memberikan cara belajar yang buruk sehingga dapat menurunkan hasil belajar siswa. Tujuan penelitian ini adalah untuk mengetahui bagaimana siswa memahami atau menyerap materi pembelajaran karena gaya belajar siswa mempengaruhi hasil belajar.

Dalyono (2012) mengatakan bahwa lingkungan sekolah memainkan peran penting dalam mengembangkan pola pikir siswa, karena fasilitas dan infrastruktur dari proses pembelajaran dan kondisi lingkungan yang menyenangkan sangat penting untuk menciptakan lingkungan yang baik. Lingkungan sekolah yaitu faktor yang bisa mempengaruhi hasil belajar siswa. Lingkungan sekolah berpengaruh dalam pelaksanaan proses pembelajaran di sekolah. Lingkungan sekolah yang baik memberikan suasana yang nyaman bagi siswa dalam melakukan kegiatan proses pembelajaran. Lingkungan sekolah yang kurang kondusif akan memberi dampak hasil belajar yang kurang memuaskan karena adanya ketidak nyamanan siswa dalam belajar di sekolah.

Menurut Indriyanti (2013) menjelaskan dalam penelitiannya bahwa ada beberapa faktor yang mempengaruhi minat melanjutkan pendidikan di Perguruan Tinggi diantaranya adalah 1) potensi diri, 2) motivasi, 3) ekspetasi masa depan, 4) peluang , 5)lingkungan sosial, 6) lingkungan sosial, 7) situasi dan kondisi serta 8) faktor institusional. Rofiah (2018) memaparkan bahwa siswa SMK lebih memilih bekerja dari pada melanjtkan untuk sekolah hal ini tersebut dipengaruhi oleh faktor pribadi, faktor lingkungan serta faktor belajar. SMK dipandang sebagai lembaga pendidikan yang dibentuk untuk memberikan bekal kepada siswa dalam memasuki lapangan kerja. Fenomena ini membuat siswa berpendapat bahwa pembelajaran dikelas hanyalah sebatas prosedur yang harus dilaksanakan untuk mendapatkan agar dapat mendapatkan gelar ijazah untuk bekal setelah lulus sekolah. Padahal dalam proses pembelajaran, lulusan SMK merupakan lulusan yang baik karena SMK selain mendapatkan ilmu pengetahuan, SMK juga memberikan ilmu praktek keterampilan pada siswa. Hal ini bisa berpengaruh pada hasil belajar siswa tersebut yang berpikiran bahwa setelah lulus sekolah mereka tidak melanjutkan pendidikan setelah itu, melainkan langsung mulai bekerja.

Dilihat dari perkembangan pembelajaran siswa kelas XI AKL di SMKN 1 Geger, masih banyak siswa yang mempunyai pola pikir bahwa setelah lulus sekolah mereka akan langsung memasuki dunia kerja sehingga proses pembelajaran siswa kurang maksimal. Masih terlihat 
banyak siswa yang kurang memperhatikan dan kurang memahami materi pembelajaran dengan sungguh-sungguh pada saat belajar di dalam kelas. Siswa beranggapan bahwa sekolah hanyalah sekedar mengikuti proses pembelajaran di sekolah sehingga kurangnya semangat belajar dalam diri siswa untuk memahami dan mempelajari pembelajaran.

Hasil belajar yang baik merupakan tujuan dari proses pembelajaran di sekolah. Hasil belajar yang diharapkan dalam proses pembelajaran ialah nilai yang tinggi sehingga sekolah dapat menghasilkan lulusan yang berkualitas. Adapun alasan menggunakan mata pelajaran tersebut dikarenakan mata pelajaran tersebut dirasa sulit untuk dipahami oleh siswa. Kesulitan itulah yang memicu peneliti untuk mengangkat mata pelajaran tersebut dalam hasil hasil belajar dikarenakan adanya tantangan tersendiri yang perlu ditaklukan oleh siswa.

Penelitian ini membahas motivasi, gaya belajar dan lingkungan sekolah terhadap hasil belajar di SMKN 1 Geger. Latar belakang ini didasarkan pada permasalahan terkait dengan permasalahan yang terdapat pada motivasi, gaya belajar dan lingkungan belajar di SMKN 1 Geger yang berminat masuk ke perguruan tinggi dan lebih memilih untuk bekerja. Motivasi dalam melaksanakan pembelajaran juga terlihat masih kurang antusias hal in dapat dilihat pada waktu pembelajaran banyak siswa yang kurang memperhatikan.

\section{TINJAUAN PUSTAKA}

\section{Pengertian Hasil Belajar}

Hasil belajar merupakan hasil dari apa yang telah dicapai oleh siswa setelah melakukan proses pembelajaran yang pada kegiatan mempelajari materi pembelajaran. Hasil belajar merupakan sebuah tujuan akhir dalam pelaksanaan kegiatan pembelajaran di sekolah. Menurut Purwanto (2011) menyebutkan bahwa hasil belajar merupakan perubahan sikap siswa setelah melakukan proses pembelajaran sesuai dengan tujuan. Hasil belajar ini merupakan realisasi dari apa yang sudah dipelajari dan juga di ketahui oleh siswa. Menurut Hutauruk dan Simbolon (2018) hasil belajar merupakan adanya pencapaian bentuk perubahan perilaku yang cenderung menetap dari ranah kognitif, afektif, dan psikomotorik dari proses belajar yang dilakukan dalam waktu tertentu.

Berdasarkan pengertian diatas maka dapat disimpulkan bahwa hasil belajar merupakan suatu pencapaian siswa yang telah melakukan proses pembelajaran yang sesuai dengan tujuan pembelajaran. Hasil belajar mencakup ranah kognitif, afektif, dan psikomotorik.

\section{Faktor-faktor yang mempengaruhi Hasil Belajar}

Keberhasilan siswa dalam belajar dapat dipengaruhi dari beberapa faktor dalam mencapai hasil belajar. Menurut Slameto (2010) Faktor-faktor yang empengaruhi hasil belajar ada dua macam yaitu, 1) Faktor internal, faktor internal adalah faktor yang berasal dari dalam diri individu, seperti faktor jasmaniah, faktor psikologis dan juga faktor kelelahan, 2) Faktor 
eskternal, faktor eksternal adalah faktor yang berasal dari luar individu, seperti faktor keluarga, faktor sekolah, faktor masyarakat. Menurut Abzani \& Leonard (2017) faktor-faktor yang dapat mempengaruhi hasil belajar dapat dijabarkan secara garis besar yaitu:

\section{Faktor internal}

Faktor internal merupakan faktor yang berasal dari dalam individu yang sedang belajar, baik dari aspek fisiologis maupun aspek psikologis suatu individu. Faktor fisiologis ini seperti faktor kesehatan, jasmani seorang indidividu. Sedangkan faktor psikologis seperti faktor intelegensi, minat, ataupun motivasi seorang individu.

\section{Faktor eksternal}

Faktor eksternal merupakan faktor yang dipengaruhi dari luar individu. Faktor eksternal dapat dilihat oleh aspek lingkungan individu dalam belajar, guru, dan juga fasilitas dalam belajar. Dapat disimpulkan bahwa faktor-faktor hasil belajar diatas dapat menjadi pendukung bagi siswa dalam proses belajar untuk mencapai hasil belajar yang baik. Faktor-faktor hasil belajar dapat dijadikan sebagai acuan yang harus diperhatikan dalam kegiatan belajar mengajar karena berpengaruh pada hasil belajar siswa nantinya.

\section{Indikator Hasil Belajar}

Penilaian hasil belajar seorang siswa mencakup beberapa ranah ataupun karakteristik. Menurut Benjamin Bloom (Sudjana 2012) hasil belajar meliputi tiga ranah yaitu: 1) Kognitif, hasil belajar kognitif yaitu meliputi tentang pengetahuan, pemahaman, penerapan, dan analisis seorang siswa; 2) Afektif, hasil belajar afektif yaitu meliputi aspek sikap, nilai, perilaku seorang siswa; dan 3) Psikomotorik, hasil belajar psikomotorik meliputi keterampilan (skill) dan kemampuan siswa dalam melaksanakan pembelajaran. Penilaian hasil belajar seorang siswa juga dapat dilihat dari kompetensi siswa seperti dijelaskan dalam Peraturan Pemerintah Republik Indonesia Nomor 13 Tahun 2015 pasal 1 Ayat (4) yang berbunyi sebagai berikut: "Kompetensi adalah seperangkat sikap, pengetahuan dan keterampilan, yang harus dimiliki, dihayati, dan dikuasai oleh Peserta Didik setelah mempelajari suatu muatan pembelajaran, menamatkan suatu program, atau menyelesaikan satuan pendidikan tertentu."

Berdasarkan pendapat diatas maka dapat disimpulkan bahwa indikator hasil belajar dapat mengacu pada Teori Bloom, indikator hasil belajar diklasifikasikan menjadi tiga yaitu: 1) Kognitif; 2) Afektif; 3) Psikomotorik. Ketiga ranah ini dapat menjadi acuan terhadap hasil belajar siswa.

\section{Motivasi}

Motivasi dan belajar merupakan sesuatu yang saling berkaitan. Pelaksanaan pembelajaran dapat berjalan dengan baik apabila siswa memiliki motivasi yang tinggi terhadap belajar. Menurut Slameto (2010) belajar merupakan suatu usaha yang dilakukan agar seseorang mendapatkan hasil dari pengalamannya sendiri. Usaha yang dilakukan untuk mendapatkan 
sebuah hasil dapat didukung dengan motivasi. Dalam pelaksanaan proses pembelajaran, siswa membutuhkan motivasi sebagai dorongan agar siswa melaksanakan kegiatan belajar. Menurut Suhana (2014) motivasi belajar merupakan kekuatan, daya pendorong, dan alat pembangun yang kuat dari siswa untuk belajar dalam rangka merubah sikap baik dalam aspek kognitif, afektif dan psikomotor.

Dari beberapa pengertian diatas, peneliti dapat menyimpulkan bahwa motivasi belajar merupakan dorongan maupun upaya siswa dalam melaksanakan kegiatan pembelajaran guna memperoleh pengalaman dan hasil belajar sesuai dengan tujuan pembelajaran.

\section{Indikator Motivasi Belajar}

Indikator motivasi belajar dapat diklasifikasikan menurut beberapa para ahli. Pada penelitian ini terdapat dua pandangan klasifikasi indikator motivasi belajar. Menurut Uno (2019) Indikator motivasi belajar dapat diklasifikasikan sebagai berikut: 1) Hasrat dan keinginan berhasil; 2) Dorongan dan kebutuhan belajar; 3) Adanya harapan dan cita-cita masa depan; 4) Penghargaan dalam belajar; 5) Kegiatan yang menarik dalam belajar; dan 6) Lingkungan belajar yang kondusif.

Pendapat lain mengenai motivasi belajar yaitu menurut Iskandar (2012) indikator motivasi belajar dapat diklasifikasikan sebagai berikut: 1) Adanya hasrat dan keinginan untuk berhasil dalam belajar; 2) Semangat dan kebutuhan dalam belajar; 3) Adanya harapan dan citacita; 4) Adanya pemberian penghargaan dalam proses belajar; 5) Lingkungan yang kondusif dalam belajar.

Dalam penelitian ini maka dapat disimpulkan indikator motivasi belajar mengacu pada teori Uno (2019) yaitu: (1) Hasrat dan keinginan berhasil, keinginan berhasil dalam proses pembelajaran dijadikan sebagai acuan motivasi belajar seorang siswa; (2) Dorongan dan kebutuhan belajar, siswa beranggapan bahwa belajar merupakan sebuah kebutuhan maka hal ini dapat dijadikan acuan sebagia motivasi dalam belajar; (3) Adanya harapan dan cita-cita masa depan, harapan dan cita-cita masa depan dapat dijadikan motivasi belajar karena siswa dapat berfokus pada apa yang di cita-citakan untuk meraih keberhasilan belajar; (4) Penghargaan dalam belajar, adanya penghargaan dalam belajar dapat memberikan motivasi belajar yang bagus untuk siswa; (5) Kegiatan yang menarik dalam belajar, kegiatan yang menarik akan membuat siswa mempunyai rasa ingin tahu dalam belajar sehingga dapat menjadikan motivasi untuk belajar; (6) Lingkungan belajar yang kondusif, lingkungan belajar yang baik dan kondusif membuat siswa nyaman dalam belajar dan meningkatkan motivasi belajar siswa.

Dapat disimpulkan bahwa indikator motivasi belajar seorang siswa berasal dari dalam diri (internal) dan juga dari luar (eksternal) yang menunjang proses pembelajaran siswa sendiri. Motivasi belajar seorang siswa tidak bisa disamakan, terdapat faktor faktor yang mempengaruhi motivasi siswa dalam proses belajar. 


\section{Gaya Belajar}

\section{Pengertian Gaya Belajar}

Gaya belajar adalah faktor yang berasal dari individu dalam menerima dan mengolah ilmu pengetahuan yang diterima. Gaya belajar merupakan suatu cara yang dilakukan siswa guna menerima pembelajaran dalam proses belajar. Menurut De Porter dan Hernacki dalam Suyono \& Hariyanto (2012) gaya belajar merupakan sebuah pemahaman seorang anak terhadap cara belajarnya untuk memahami pembelajaran guna mendapatkan manfaat pembelajarannya. Pembelajaran dapat diserap dan diolah dengan mudah dan lebih baik apabila siswa dapat belajar dengan gaya belajarnya sendiri. Gaya belajar dipahami sebagai cara yang dilakukan oleh siswa dalam mengolah informasi yang diperoleh dalam aktivitas belajar (Koeron dkk, 2014). Gaya belajar merupakan kemampuan individu dalam menangkap dan memahami pelajaran yang berbeda tingkatnya (Uno, 2012).

Dari pendapat beberapa ahli maka dapat disimpulkan bawa gaya belajar merupakan cara suatu individu dalam menerima pelajaran. Setiap individu memiliki kemampuan yang berbeda dalam cara menangkap pembelajaran. Hal ini tergantung dalam cara belajar suatu individu.

\section{Jenis-jenis Gaya Belajar}

Setiap individu memilik gaya belajar yang berbeda-beda, ada yang lebih senang dalam bentuk gambar, mendengarkan suara, dan juga praktik langsung dalam pembelajaran. dalam hal ini, siswa akan cenderung pada salah satu diantara gaya belajar tersebut. Seperti yang dijelaskan DePorter dan Henarcki (Suyono \& Hariyanto 2012) terdapat tiga gaya belajar individu yaitu gaya belajar visual, auditorial dan kinestetik.

\section{Gaya Belajar Visual (Visual Learners)}

Siswa yang belajar dengan gaya visual selalu menggunakan indera mata/penglihatan dalam menangkap informasi ataupun materi. Siswa belajar dari apa yang mereka lihat. Siswa dapat menggunakan pembelajaran yang berbentuk gambar maupun sebuah video untuk dapat lebih cepat menangkap serta menganalisis di otak siswa.

Gaya belajar visual memiliki berbagai macam ciri-ciri. Menurut Suyono dan Hariyanto (2012) Ciri-ciri gaya belajar visual adalah: 1) Teratur dan suka kerapihan; 2) Sulit menerima intruksi lisan; 3) Detail; 4) Mengingat apa yang dilihat, daripada apa yang didengar; 5) Tidak terganggu pada keributan; dan 6) Menjawab pertanyaan langsung pada intinya. Pendapat lain mengenai ciri-ciri gaya belajar visual menurut Khoeron (2014) yaitu: rapi serta terperinci; terstruktur dan perencana yang baik; teliti terhadap sesuatu; tidak terganggu oleh keributan; memperhatikan penampilan; mengingat apa yang dilihat daripada apa yang didengar; suka membaca. 
Dapat disimpulkan bahwa gaya belajar visual selalu memperhatikan dan mempusatkan ketajaman penglihatan siswa dalam mempelajari maupun menerima informasi dalam proses pembelajaran.

\section{Gaya Belajar Auditorial (Auditory Learners)}

Siswa yang belajar dengan gaya auditorial selalu menggunakan indera telinga/pendengaran dalam memahami dan menangkap informasi ataupun pengetahuan. Siswa akan mendengarkan suatu informasi lalu siswa dapat menangkap informasi yang didapat. Siswa yang memilik gaya beajar auditorial biasanya cenderung menghafal apa yang dikatakan oleh guru ataupun dengan cara membaca suatu teks dan juga mendengarkan materi dalam bentuk audio.

Gaya belajar auditorial memiliki berbagai macam ciri-ciri. Menurut Suyono \& Hariyanto (2012) ciri-ciri gaya belajar auditorial yaitu: berbicara fasih; lebih senang mendengarkan dan suka membaca dengan keras; suka diskusi; suka musik; mudah terganggu terhadap keributan; kesulitan dalam menulis.

Sedangkan pendapat lain mengenai ciri-ciri gaya belajar auditorial menurut Khoeron (2014) yaitu: suka berbicara sendiri pada saat kegiatan; terganggu pada keributan; membaca dengan bersuara untuk mengingat; pembicara yang baik; lebih suka mendengarkan musik daripada seni. Dapat disimpulkan bahwa gaya belajar auditorial mempusatkan atau mengandalkan indera pendengaran dalam menyerap informasi dalam proses pembelajaran.

\section{Gaya Belajar Kinestetik (Kinesthetic Learners)}

Siswa yang memiliki gaya belajar kinestetik cenderung lebih dapat menangkap materi pembelajaran ketika berdiskusi dan melakukan gerak fisik. Siswa lebih menyukai belajar dengan cara mempraktekkan langsung materi yang diterima. Siswa dapat menangkap materi dan menghafal dengan cara berjalan ataupun melihat langsung. Siswa lebih senang terjun langsung kelapangan dalam kegiatan belajar.

Gaya belajar kinestetik dapat diklasifikasikan ciri-cirinya menurut beberapa para ahli. Menurut Sundayana (2016) Ciri-ciri gaya belajar kinestetik adalah: 1) Pelan dalam berbicara; 2) Lebih banyak gerak dan berotientasi pada fisik; 3) Tidak dapat diam lama; 4) Belajar dengan praktik; 5) Peka. Berbeda dengan Khoeron (2014) ciri-ciri gaya belajar kinestetik yaitu: berbicara dengan hati-hati; menggunakan isyarat tubuh dalam berbicara; tidak dapat berdiam diri dengan waktu yang lama; lebih senang praktik dan banyak bergerak; menghapal dengan cara bergerak; melakukan pembelajaran dengan menyentuh.

Melihat ketiga gaya belajar diatas, dapat diketahu setiap individu memiliki kemampuan yang berbeda beda dalam menyerap dan menangkap informasi dalam pembelajaran. Gaya belajar siswa yang berbeda-beda memberikan keunikan sendiri dalam cara belajar sehingga dapat membantu siswa dalam mencapai hasil belajar yang ingin dicapai. 


\section{Indikator Gaya Belajar}

Banyak macam gaya belajar yang diterapkan oleh siswa. gaya belajar menurut DePorter dan Hernacki terdapat tiga macam yaitu gaya belajar visual, auditorial dan kinestetik. Gaya belajar visual dimana siswa belajar dengan cara melihat lewat gambaran. Gaya belajar auditorial dimana siswa belajar dengan cara mendengarkan, serta gaya belajar kinestetik dimana siswa belajar dengan cara praktik atau gerak.

Widayanti (2013) menuliskan dalam artikelnya bahwa kemampuan siswa dalam memahami pelajaran. Setiap siswa memiliki cara belajar yang berbeda beda dan harus ditempuh dan dipahami dengan baik. Tiga jenis gaya belajar menurut Widayanti yaitu: 1) gaya belajar visual, yang dipahami dengan menggunakan indera penglihatan.; 2) gaya belajar auditorial, yang dipahami dengan menggunakan indera pendengaran.; 3) gaya belajar kinestetik, yang dipahami dengan menyentuh sesuatu agar dapat diingat.

Berdasarkan teori gaya belajar diatas, maka dapat disimpulkan indikator gaya belajar mengacu pada teori DePorter dan Hernacki pada Suyono \& Hariyanto (2012) yang dapat diklasifikasikan dalam 3 (tiga) indikator yaitu: (1) Gaya Belajar Visual; (2) Gaya Belajar Auditorial; (3) Gaya Belajar Kinestetik.

\section{Lingkungan Sekolah}

\section{Pengertian Lingkungan Sekolah}

Lingkungan sekolah merupakan lingkungan yang menjadi tempat belajar seorang siswa. Menurut Dalyono (2012) lingkungan sekolah berperan penting dalam mengembangkan pola pikir anak, karena sarana dan prasarana dalam proses belajar dan juga kondisi lingkungan yang nyaman sangat penting untuk terciptanya lingkungan belajar yang baik. Menurut Muhibbin Syah (2013) lingkungan sekolah terbagi menjadi dua yaitu lingkungan sosial dan lingkungan nonsosial. Lingkungan sosial terdiri dari guru, tenaga pendidikan, teman teman sekelas. Sedangkan lingkungan nonsosial seperti gedung sekolah, alat belajar, dan waktu belajar.

Berdasarkan beberapa pendapat diatas, maka dapat disimpulkan bahwa lingkungan sekolah merupakan kondisi lingkungan tempat belajar dan mengajar untuk dapat mengembangkan potensi siswa. kondisi ini terdapat lingkungan sosial dan lingkungan nonsosial yang dapat berpengatuh terhadap siswa untuk pelaksanaan proses belajar dan mengajar di sekolah.

\section{Indikator Lingkungan Sekolah}

Keberhasilan seorang siswa dapat dipengaruhi oleh lingkungan belajar siswa. Menurut Slameto (2010) faktor lingkungan sekolah yang mempengaruhi hasil belajar siswa yaitu: 1) metode mengajar yang dipilih guru; 2) kurikulum pendidikan; 3) hubungan guru dengan siswa; 4) hubungan siswa dengan siswa; 5) tata tertib sekolah; 6) fasilitas sekolah; 7) keadaan gedung sekolah; 8) metode belajar siswa. 
Pendapat lain yang disampaikan menurut Syah (2013) Indikator lingkungan sekolah dapat di klasifikasikan sebagai yaitu: 1) Lingkungan Sosial Sekolah seperti guru, tenaga kependidikan, dan teman teman sekelas; 2) Lingkungan nonsosial seperti gedung sekolah, alatalat belajar, cuaca dan keadaan sekolah.

Berdasarkan teori diatas, dapat disimpulkan bahwa indikator sekolah terdiri dari lingkungan akademis, lingkungan sosial dan lingkungan non sosial. Dalam penelitian ini indikator Lingkungan Sekolah mengacu pada teori Syah (2013) yaitu lingkungan Sosial Sekolah yang terdiri seperti: 1) Guru, guru yang baik menciptakan suasana belajar yang baik; 2) Tenaga kependidikan, tenaga kependidikan mengerti dan memahami mengenai lingkungan sekolah yang baik; 3) Teman-teman sekelas, teman-teman sekelas dapat menciptakan suasana lingkungan sekolah yang nyaman agar proses pembelajaran dikelas menyenangkan.

Selain lingkungan sosial terdapat lingkungan nonsosial yang yang terdiri dari: 1) Gedung sekolah, gedung sekolah yang layak dan baik dapat memberikan lingkungan sekolah yang nyaman; 2) Alat-alat belajar, alat-alat belajar yang tersedia dan layak digunakan untuk kegiatan belajar mengajar; 3) Keadaan cuaca dan waktu belajar, keadaan cuaca dan waktu belajar dapat menciptakan suasana lingkungan belajar yang baik dan nyaman bagi siswa.

\section{METODE PENELITIAN}

Jenis penelitian ini yaitu penelitian kuantitatif untuk menguji pengaruh variabel bebas yaitu Motivasi, Gaya Belajar dan Lingkungan Sekolah terhadap variabel terikat yaitu Hasil Belajar. Populasi penelitian ini yaitu siswa kelas XI program keahlian Akuntansi dan Keuangan Lembaga di SMKN 1 Geger yang berjumlah 94 siswa.

Tabel 3.1. Jumlah Populasi Penelitian

\begin{tabular}{cc}
\hline Kelas & Jumlah Siswa \\
\hline XI AKL 1 & 28 \\
\hline XI AKL 2 & 32 \\
\hline XI AKL 3 & 34 \\
\hline Jumlah & 94 \\
\hline
\end{tabular}

Teknik Pengambilan sampel ini berpedoman pada teknik slovin (Darmawan, 2019)

$$
\begin{gathered}
n=\frac{N}{1+N e^{2}} \\
\text { Keterangan: } \\
\mathrm{n}=\text { sampel } \\
N=\text { populasii } \\
\mathrm{E}=\text { perkiraan tingkat kesalahan }
\end{gathered}
$$

Berdasarkan rumus maka cara yang digunakan dalam menentukan sampel yaitu:

$$
\begin{gathered}
n=\frac{94}{1+94(0,05)^{2}} \\
n=\frac{94}{1+94(0,0025)}
\end{gathered}
$$




$$
\begin{gathered}
n=\frac{94}{1+0,235} \\
n=\frac{94}{1,235}=76,1136 \approx 76 \text { siswa }
\end{gathered}
$$

Teknik Pengambilan sample yang digunakan pada penelitian ini yaitu Probability Sampling dengan Simple Random Sampling. jumlah sampel sebesar 76 siswa dipilih secara acak dari 94 populasi siswa kelas XI AKL SMKN 1 Geger.

\section{HASIL DAN PEMBAHASAN}

\section{Analisis Statistik Deskriptif}

Hasil analisis statistik deskriptif diperoleh temuan penelitian motivasi (X1) dengan nilai terbawah sebesar 17, nilai tertinggi sebesar 42 , nilai rata-rata sebesar 30.05 serta nilai simpangan baku sebesar 6.56. sedangkan untuk Gaya belajar (X2) dengan nilai terbawah sebesar 27, nilai tertinggi sebesar 52, nilai rata-rata sebesar 41.47 serta nilai simpangan baku sebesar 6.56. untuk Lingkungan Sekolah (X3) dengan nilai terbawah sebesar 24, nilai tertinggi sebesar 52 , nilai rata-rata sebesar 37.82 serta nilai simpangan baku sebesar 7.59. untuk Hasil Belajar (Y) dengan nilai terbawah sebesar 79, nilai tertinggi sebesar 94.93, nilai rata-rata sebesar 86.34 serta nilai simpangan baku sebesar 4.78 .

\section{Uji Hipotesis}

\section{Persamaan Regresi Berganda}

$\mathrm{H}_{\text {belajar }}=62.278+0.244 *$ Motivasi $+0.117 * \mathrm{G}_{\text {belajar }}+0.314 * \mathrm{~L}_{\text {sekolah }}$

Berdasarkan persamaan di atas, maka persamaan regresi berganda ditulis sebagai berikut 1) Ketika keseluruhan variabel bebas bernilai 0 atau konstant, maka hasil belajar akan bernilai $62.278,2$ ) Setiap kenaikan satu satuan pada variabel motivasi belajar dan variabel lain bernilai konstant atau 0, maka hasil belajar akan naik sebesar 0.244, 3) Setiap kenaikan satu satuan pada variabel gaya belajar dan variabel lain bernilai konstant atau 0 , maka hasil belajar akan naik sebesar 0.117 , 4) Setiap kenaikan satu satuan pada variabel lingkungan sekolah dan variabel lain bernilai konstant atau 0 , maka hasil belajar akan naik sebesar 0.314 .

\section{Uji Parsial T}

Tabel 2. Hasil Uji Parsial T

\section{Coefficients ${ }^{a}$}

\begin{tabular}{rcccccc}
\hline \multirow{2}{*}{ Model } & \multicolumn{2}{c}{$\begin{array}{c}\text { Unstandardized } \\
\text { Coefficients }\end{array}$} & $\begin{array}{c}\text { Standardize } \\
\mathrm{d} \\
\text { Coefficients }\end{array}$ & $\mathrm{t}$ & Sig. \\
\cline { 2 - 5 } & $\mathrm{B}$ & Std. Error & Beta & & \\
\hline (Constant) & 62.278 & 1.832 & & 33.989 & .000 \\
1 & Motivasi & .244 & .068 & .334 & 3.566 & .001 \\
& Gbelajar & .117 & .050 & .161 & 2.345 & .022 \\
Lsekolah & .314 & .054 & .499 & 5.779 & .000 \\
& \multicolumn{7}{l}{ a. Dependent Variable: HBelajar } \\
\hline
\end{tabular}

Sumber: Hasil Pengolahan SPSS Versi 25 
Berdasarkan tabel 2. Uji Parsial T, maka dirumuskan temuan penelitian yaitu: 1) Terdapat pengaruh yang signifikan dan positif Motivasi $\left(\mathrm{X}_{1}\right)$ terhadap hasil belajar, temuan ini dibuktikan dengan koefisien t hitung sebesar 3.566 serta koefisien sig $=0.001<0.05,2$ ) Terdapat pengaruh yang signifikan dan positif Gaya Belajar $\left(\mathrm{X}_{2}\right)$ terhadap hasil belajar, temuan ini dibuktikan dengan koefisien t hitung sebesar 2.345 serta koefisien sig $=0.022<0.05$. Terdapat pengaruh yang signifikan dan positif Lingkungan Sekolah $\left(\mathrm{X}_{3}\right)$ terhadap hasil belajar, temuan ini dibuktikan dengan koefisien t hitung sebesar 5.779 serta koefisien sig $=0,000<0.05$.

Uji Simultan F

Tabel 3. Uji Anova

ANOVA $^{\mathrm{a}}$

\begin{tabular}{ccccccc}
\hline \multirow{2}{*}{ Model } & $\begin{array}{c}\text { Sum of } \\
\text { Squares }\end{array}$ & Df & Mean Square & F & Sig. \\
\hline \multirow{3}{*}{1} & Regression & 1331.263 & 3 & 443.754 & 82.339 & $.000^{\mathrm{b}}$ \\
\cline { 2 - 5 } & Residual & 388.033 & 72 & 5.389 & & \\
Total & 1719.295 & 75 & & \\
\multicolumn{5}{c}{ a. Dependent Variable: HBelajar } \\
\multicolumn{5}{c}{ bumber: Hasil Pengolahan SPSS Versi 25 }
\end{tabular}

Berdasarkan tabel 3. Uji simultan F yang disajikan di atas, diperoleh temuan penelitian bahwa terdapat pengaruh yang signifikan dan simultan Motivasi $\left(\mathrm{X}_{1}\right)$, Gaya Belajar $\left(\mathrm{X}_{2}\right)$ dan Lingkungan Sekolah $\left(\mathrm{X}_{3}\right)$ terhadap Hasil Belajar $(\mathrm{Y})$, yang dibuktikan dengan koefisien sig $=0.000$ $<0.05$.

\section{Pengaruh Motivasi Terhadap Hasil Belajar}

Berdasarkan uji parsial t dengan menggunakan uji regresi linear berganda berbantuan software IBM for SPSS versi 25 diperoleh temuan penelitian bahwa $t_{\text {hitung }}$ untuk variabel motivasi sebesar 3.566 dengan nilai koefisien signifikan sebesar 0.001 ( $\mathrm{sig}<0.05$ ). Artinya bahwa motivasi berpengaruh signifikan dan positif terhadap hasil belajar, temuan penelitian ini dibuktikan dengan koefisien sig yang lebih kecil dibandingkan dengan taraf signifikansi alpha serta koefisien beta yang bernilai positif.

Hal ini sesuai dengan pernyataan tertinggi yang berbunyi "Saya giat belajar karena saya tahu manfaat belajar", hal tersebut mengindikasikan bahwa motivasi belajar siswa yang tinggi akan membuat siswa semakin giat dalam belajar, maka siswa akan merasakan manfaat belajar seperti mendapatkan hasil belajar yang memuaskan. Pernyataan ini selaras dengan Penelitian dari Daud (2012) yang menemukan bahwa adanya pengaruh positif motivasi belajar yang ditimbulkan terhadap hasil belajar siswa. hal yang didapat dari penelitian ini adalah bahwa motivasi belajar mempunyai pengaruh terhadap hasil belajar seorang siswa. Jika siswa termotivasi tinggi untuk belajar, siswa akan mendapatkan hasil belajar yang baik untuk dirinya sendiri. Namun sebaliknya jika siswa tidak memliki motivasi yang tinggu untuk belajar, siswa akan mendapatkan hasil yang buruk terkait hasil belajarnya. 


\section{Pengaruh Gaya Belajar terhadap Hasil Belajar}

Berdasarkan uji parsial $t$ dengan menggunakan uji regresi linear berganda berbantuan software IBM for SPSS versi 25 diperoleh temuan penelitian bahwa $t_{\text {hitung }}$ untuk variabel gaya belajar sebesar 2.345 dengan nilai koefisien signifikan sebesar 0.022 (sig < 0.05). Artinya ada pengaruh yang signifikan dan postifi gaya belajar terhadap hasil blajar, temuan penelitian ini dibuktikan dengan koefisien sig yang lebih kecil dibandingkan dengan taraf signifikansi alpha serta koefisien beta yang bernilai positif.

Hasil penelitian ini menunjukan bahwa gaya belajar siswa mempengaruhi hasil belajar. Hal ini mengindikasikan bahwa dengan semakin meningkatnya gaya belajar yang dimiliki oleh responden, maka akan semakin meningkat pula hasilnbelajar, dan sebaliknya dengan semakin menurunnya gaya belajar makan semakin menurun pula hasil belajar yang dimiliki oleh responden. Siswa dapat mencapai hasil belajar yang baik jika memiliki gaya belajar yang sesuai dengan kepribadiannya. Sebaliknya apabila siswa tidak bisa menyesuaikan gaya belajar dengan kepribadian siswa itu sendiri, maka hasil belajar yang dicapai siswa tersebut kurang baik.

Hal ini sesuai dengan pernyataan tertinggi yang berbunyi "Saya senang apabila diminta mempraktikkan sebuah peragaan di depan kelas", hal ini mengindikasikan bahwa dalam siswa SMKN 1 Geger mayoritas lebih cenderung menyukai pembelajaran yang mengarah pada praktek ketimbang pembelajaran yang hanya berkisar pada teori saja. Pembelajaran dengan praktek lebih menarik perhatian siswa dikarenakan pembelajaran ini memicu motivasi belajar dan semangat belajar pada siswa. Gaya belajar yang sesuai dengan kepribadian siswa akan meningkatkan motivasi belajar sehingga hasil belajar pun akan meningkat seiring dengan gaya belajar yang dilakukan dalam kelas sesuai dengan kepribadian siswa.

Penelitian ini slelaras dengan penelitian Khoeron dkk (2014) yang mengemukakan bahwa adanya pengaruh positif gaya belajar yang ditimbulkan terhadap hasil belajar seorang siswa. Siswa yang dapat memahami bagaimana gaya belajarnya, akan memudahkan siswa dalam proses pembelajaran.

\section{Pengaruh Lingkungan Sekolah Terhadap Hasil Belajar}

Berdasarkan uji parsial t dengan menggunakan uji regresi linear berganda berbantuan software IBM for SPSS versi 25 diperoleh temuan penelitian bahwa $t_{\text {hitung }}$ untuk variabel lingkungan sekolah sebesar 5.779 dengan nilai koefisien sebesar 0.000 ( $\mathrm{sig}<0.05$ ). Hal ini berarti terdapat pengaruh yang signifikan dan positiflingkungan sekolah terhadap hasil belajar, temuan penelitian ini dibuktikan dengan koefisien sig yang lebih kecil dibandingkan dengan taraf signifikansi alpha serta koefisien beta yang bernilai positif.

Hasil penelitian menunjukkan bahwa lingkungan sekolah mempengaruhi hasil belajar siswa. Hal ini mengindikasikan bahwa dengan semakin seiring meningkatnya kualitas sekolah 
yang dimiliki responden, maka akan mempengaruhi hasil belajar siswa, dan begitu pula sebaliknya.

Hal ini sesuai dengan pernyataan "Perpustakaan sekolah lengkap dengan buku-buku penunjang", hal ini mengartikan bahwa buku yang merupakan salah satu fasilitas untuk belajar pada siswa SMKN 1 Geger sudah mampu menunjang kegiatan belajar mengajar. Hal tersebut dikarnakan SMK merupakan sekolah yang lebih mengarah pada kualitas praktek saat kegiatan belajar megajar sehingga perlu adanya buku yang bekualitas baik agar materi pembelajaran dapat tersampaikan dengan baik.

Penelitian yang mendukung temuan ini adalah penelitian yang dilakukan oleh Martina (2019) yang menemukan bahwa adanya pengaruh yang ditimbulkan dari lingkungan sekolah terhadap hasil belajar siswa. Hal yang didapat dari penelitian ini adalah semakin baik lingkungan sekolah, semakin baik pula hasil belajar seorang siswa.

\section{Pengaruh Motivasi, Gaya Belajar dan Lingkungan Sekolah terhadap Hasil Belajar}

Berdasarkan hasil uji simultan $\mathrm{F}$ dengan menggunakan uji regresi liner bergandan berbantuan software IBM for spss versi 25 diperoleh temuan penelitian bahwa terdapat pengaruh yagn signifikan dan simultan motivasi belajar, gaya belajar dan lingkungan sekolah terhadap hasil belajar, temuan penelitian ini dibuktikan dengan koefisien sig yang lebih kecil dibandingkan dengan taraf signifikansi alpha, hal ini mengindikasikan bahwa dengan adanya motivasi belajar, gaya belajar, dan lingkungan sekolah secara serentak mampu memberikan pengaruh yang signifikan terhadap hasil belajar. Dilihat dari uji hipotesis sebelumnya, terdapat pengaruh yang signifikan dan positif terhadap hasil belajar. Motivasi belajar, gaya belajar dan lingkungan sekolah apabila dilakukan secara bersama-sama dapat saling berhubungan dan memberikan hasil yang baik terhadap hasil belajar.

\section{KESIMPULAN}

Motivasi belajar berpengaruh signifikan dan positif terhadap hasil belajar siswa. Semakin tinggi kemauan belajar siswa maka akan semakin tinggi hasil belajar siswa yang didapatkan, sebaliknya jika semakin rendah kemauan belajar siswa dalam belajar maka semakin rendah hasil belajar yang dicapai oleh siswa. Motivasi belajar siswa yang tinggi akan membuat siswa semakin giat dalam belajar, maka siswa akan merasakan manfaat belajar seperti mendapatkan hasil belajar yang memuaskan. Hal ini dapat berimbas pada hasil belajar siswa SMKN 1 Geger.

Gaya belajar memiliki pengaruh yang signifikan dan positif terhadap hasil belajar siswa. hal tersebut mengindikasikan bahwa gaya belajar seorang siswa berbeda-beda. Apabila gaya belajar siswa sudah sesuai. dengan kepribadiannya, maka akan mempercepat siswa dalam proses belajar dan akan memberikan hasil belajar yang unggul tergantung pada apa yang ingin siswa capai, begitu pula sebaliknya apabila gaya belajar seorang siswa tidak sesuai dengan kepribadiannya, maka akan mempersulit siswa dalam proses belajar dan menjadi hambatan 
untuk mencapai tujuan belajar. Siswa SMKN 1 Geger mayoritas lebih cenderung menyukai pembelajaran yang mengarah pada praktek ketimbang pembelajaran yang hanya berkisar pada teori saja. Pembelajaran dengan praktek lebih menarik perhatian siswa dikarenakan pembelajaran ini memicu motivasi belajar dan semangat belajar pada siswa.

Lingkungan sekolah memiliki pengaruh yang signifikan dan positif terhadap hasil belajar siswa. Hal ini menandakan bahwa lingkungan sekolah yang baik berdampak postif terhadap hasil belajar siswa di sekolah, begitu pula sebaliknya. SMKN 1 Geger sudah memberikan fasilitas yang baik untuk kegiatan pembelajaran. buku-buku yang merupakan salah satu fasilitas lingkungan sekolah, sudah disediakan di perpustakaan sekolah untuk digunakan siswa SMKN 1 Geger pada kegiatan proses pembelajaran.

Motivasi belajar, gaya belajar dan lingkungan sekolah yang memiliki pengaruh signifikan dan simultan terhadap hasil belajar siswa. Hal ini menunjukkan bahwa motivasi belajar, gaya belajar dan lingkungan sekolah secara serentak dapa menjadi pengaruh yang signifikan dan simultan terhadap hasil belajar siswa. hal ini akan terlihat apabila seorang siswa memiliki motivasi belajar dan gaya belajar yang sesuai serta didukung oleh lingkungan yang baik, maka siswa tersebut dapat mencapai hasil belajar yang baik.

\section{DAFTAR PUSTAKA}

Abzani, A., \& Leonard, L. (2017). Pengaruh Locus Of Control Terhadap Kemampuan Pemecahan Masalah Matematika.

Darmawan. (2019). Metode Penelitian Kuantitatif. Bandung: PT Remaja Rosdakarya.

Dalyono, M. (2012). Psikologi Pendidikan. Jakarta: Rieneka Cipta.

Daud, F. (2012). Pengaruh kecerdasan emosional (EQ) dan motivasi belajar terhadap hasil belajar Biologi siswa SMA 3 Negeri Kota Palopo. Jurnal Pendidikan dan Pembelajaran (JPP), 19(2), 243-255.

Iskandar. (2012). Psikologi Pendidikan Sebuah Orientasi Baru. Cipayung-Ciputat: Gaung Persada (GP) Press.

Indriyanti, N., Siswandari, S., \& Ivada, E. (2013). Faktor-Faktor Yang Memengaruhi Minat Melanjutkan Pendidikan Ke Perguruan Tinggi Pada Siswa Kelas Xii Akuntansi Smk Negeri 6 Surakarta Tahun 2013. Jurnal Pendidikan Ekonomi Universitas Sebelas Maret, 1(2), 13560.

Indonesia. (2005). Peraturan Pemerintah Republik Indonesia nomor 19 tahun 2005 tentang standar nasional pendidikan. Departemen Pendidikan Nasional Republik Indonesia.

Khoeron, I. R. (2014). Pengaruh Gaya Belajar Terhadap Prestasi Belajar Peserta Didik Pada Mata Pelajaran Produktif: Studi Kasus di SMK Negeri 8 Kota Bandung (Doctoral dissertation, Universitas Pendidikan Indonesia).

Martina, M., Khodijah, N., \& Syarnubi, S. (2019). Pengaruh Lingkungan Sekolah Terhadap Hasil Belajar Siswa Pada Mata Pelajaran Pendidikan Agama Islam Di SMP Negeri 9 Tulung Selapan Kabupaten Oki. Jurnal PAI Raden Fatah, 1(2), 164-180.

Purwanto. (2011). Evaluasi Hasil Belajar. Yogyakarta: Pustaka Pelajar.

Slameto. (2010). Belajar dan faktor-faktor yang mempengaruhi. Jakarta: Rineka cipta. 
Syah, Muhibbin. (2013). Psikologi Pendidikan, Dengan Pendekatan Baru. Bandung: PT Remaja Rosdakarya.

Sudjana, Nana. (2012). Penelitian Hasil Proses Belajar Mengajar. Bandung: Remaja Rosda Karya.

Suhana, Cucu. (2014). Konsep Strategi Pembelajaran. Bandung. PT. Refika Aditama.

Sundayana, R. (2016). Kaitan antara gaya belajar, kemandirian belajar, dan kemampuan pemecahan masalah siswa SMP dalam pelajaran matematika. Mosharafa: Jurnal Pendidikan Matematika, 5(2), 75-84.

Suyono \& Hariyanto. (2012). Belajar dan Pembelajaran. Bandung: Remaja Rosdakarya.

Uno, Hamzah B. (2019). Teori Motivasi dan Pengukurannya. Jakarta: PT Bumi Aksara. Hutauruk, P., \& Simbolon, R. (2018). Meningkatkan hasil belajar siswa dengan menggunakan alat peraga pada mata pelajaran IPA kelas IV SDN Nomor 14 Simbolon Purba. School Education Journal PGSD FIP Unimed, 8(2), 121-129.

Urfan, F. (2016). Pengaruh Lingkungan Sekolah terhadap Kecerdasan Spasial Peserta Didik melalui Affordance dan Geo-Literacy menggunakan Analisis Jalur (Studi Kasus SMA Negeri di Kota Bandung dan Kabupaten Bandung). Jurnal Geografi Gea, 16(2), 105-115.

Widayanti, F. D. (2013). Pentingnya Mengetahui Gaya Belajar Siswa Dalam Kegiatan Pembelajaran Di Kelas. Erudio Journal of Educational Innovation, 2(1) 